\title{
QUASE LÁ: A COPA DO MUNDO NO ITAQUERÃOO E OS IMPACTOS DE UM MEGAEVENTO NA SOCIALIDADE TORCEDORA*
}

\section{Luiz Henrique de Toledo Universidade Federal de São Carlos - Brasil}

Resumo: Em meio às controvérsias políticas e esportivas locais, ampliadas no nível global por ocasião do megaevento da Copa do Mundo de futebol está sendo erguido em Itaquera, zona leste da capital paulistana, o estádio-sede do Sport Club Corinthians Paulista, arena escolhida para a abertura do grande evento em 2014. Este artigo tem por finalidade apresentar os primeiros resultados da pesquisa de campo que venho realizando no entorno da construção do referido estádio e o ponto de vista privilegiado é perceber o modo como os torcedores produzem e constroem os alicerces simbólicos sobre a edificação monumental. Meu enfoque é retomar as dinâmicas do torcer numa metrópole como São Paulo, onde o exercício contrastivo torcedor captura um momento em que um megaevento orienta em boa medida as disputas pelos espaços da cidade e as redefinições de uma forma de torcer denominada corintianismo.

Palavras-chave: antropologia das práticas esportivas, cidade de São Paulo, formas de torcer, megaevento esportivo.

Abstract: Under local sporting and political controversies, amplified at the global level for the mega event of FIFA's World Cup, is being constructed in Itaquera, a neighborhood at the east side of São Paulo, the home-stadium of the Sport Club Corinthians Paulista, arena chosen for opening the big event in 2014. This article aims to present the first results of the fieldwork I have been doing at the surrounds of

* Este artigo é fruto de pesquisa vinculada ao LUDENS (Núcleo Interdisciplinar de Pesquisas sobre Futebol e Modalidades Lúdicas da USP) e ao LELuS (Laboratório de Estudos das práticas lúdicas e sociabilidade - UFSCar, CNPq). Agradeço o antropólogo Piero de Camargo Leirner e os pareceristas anônimos que contribuíram com críticas e sugestões.

Horizontes Antropológicos, Porto Alegre, ano 19, n. 40, p. 149-184, jul./dez. 2013 
the construction of this stadium, and assuming the vantage point to understand how the fans produce and build the symbolic foundations of this monumental building. My aim here is to resume the dynamics of football fans in a city as São Paulo, where the contrast between different club supporters captures a single moment in which a mega event yields disputes and feuds for the city spaces and resets a way to support the team called corintianismo.

Keywords: anthropology of sports practices, mega sports events, São Paulo, styles of supporter.

\section{A copa, a cidade e o estádio}

Este artigo discute os impactos no imaginário torcedor das obras do estádio de posse do Sport Club Corinthians Paulista edificado no bairro de Itaquera, São Paulo, que sediará parte do megaevento da Copa do Mundo em 2014. Procurarei articular, pela via etnográfica, três níveis de observação: a ocorrência do aludido megaevento, fenômeno considerado de ordem global, ${ }^{1}$ somado a outros dois que tomo por locais, sendo que um está imediatamente relacionado à realização da Copa do Mundo, pois se trata de um legado em si, ${ }^{2}$ a construção do estádio que abrigará, entre outros, o jogo inaugural do torneio, e ambos associados a um terceiro fenômeno ainda mais local que identifico como sendo um legado intangível (Poyter, 2008) e que diz respeito à dinâmica simbólica torcedora presente na cidade.

Aí, nesse último nível, discutirei mais detidamente o fenômeno do corintianismo, seja como expressão da vontade torcedora envolta ao legado deixado pelo megaevento, seja na caracterização de uma das formas de torcer (Toledo, 2002, 2012a) específicas que ganha nova roupagem num momento de efervescência esportiva por que passa o Sport Club Corinthians Paulista, fruto da política gerencial capitaneada por dirigentes mais hábeis no trato e costura

\footnotetext{
1 Alguns autores definem a escala global dos megaeventos esportivos como " [...] eventos cuja globalidade não se mede apenas pela mobilização de praticamente todas as nações do mundo, afiliadas às respectivas entidades organizadoras internacionais [COI, FIFA] e desejosas de participação nos certames; trata-se de constatar a dimensão simbólica adquirida por tais eventos, capazes de atrair as atenções em todo o planeta, promovendo fantásticos rituais periódicos, sem parâmetro de comparação com nenhum outro fenômeno social" (Mascarenhas, 2009, p. 506).

2 Legado em si, legado da candidatura do evento, legado da imagem do Brasil, legado de governança e legado de conhecimento formam a tipologia oferecida por Lamartine da Costa e Ana Miragaya (2008).
}

Horizontes Antropológicos, Porto Alegre, ano 19, n. 40, p. 149-184, jul./dez. 2013 
política, trazendo títulos aos torcedores bem como reposicionando a marca Corinthians no contexto do marketing esportivo moderno. ${ }^{3}$ As articulações em torno da confirmação da Copa do Mundo na cidade e em seu estádio faz parte desse momento considerado virtuoso pelos seus dirigentes e aficionados.

Não estou definindo a intangibilidade do legado a partir dos mesmos fenômenos pelos quais alguns autores atentos aos megaeventos esportivos a recortam, mas vale a formulação mais geral de que "algumas análises têm sugerido que as cidades-sedes se beneficiam mais do intangível do que do tangível. Isto é particularmente evidenciado em termos de marca e no marketing da cidade bem como no aumento do orgulho cívico ou nacional [...]." (Poyter, 2008, p. 139).

Não obstante, as alegações de que tal legado intangível em São Paulo passa por uma espécie de privatização simbólica com nítido favorecimento ao clube é uma opinião que se percebe quando ouvidas as manifestações tanto de torcedores, mesmo entre corintianos, quanto de parte das opiniões veiculadas na mídia. É a Itaquera corintiana, até o momento, mais do que a zona leste ou a metrópole paulistana como um todo, que vem adquirindo visibilidade, e nesse sentido dilui-se o tom mais ufanista em torno da imagem da cidade. $\mathrm{O}$ nacionalismo ainda não aflorou, e o que se tem, de fato, mobilizando a opinião pública em torno do megaevento é a construção do estádio para o Corinthians.

Tratarei, então, de averiguar como a expressão de um orgulho identitário clubístico e contrastivo local tão presente na dinâmica torcedora ampliou seu repertório simbólico desde que o megaevento Copa do Mundo tornou exequível a construção do estádio.

Sendo assim, a escolha política do local na cidade, o populoso bairro de Itaquera na zona leste, e do terreno subutilizado do Corinthians como espaço da edificação do estádio para a Copa do Mundo confluem para o adensamento

3 "Em 2012, o clube paulista teve sua marca avaliada em R\$ 1,05 milhões, acréscimo de 16\% em relação a 2011. Só para se ter uma ideia, em 2004, o Timão registrava 286 milhões, ou 252\% a menos que do angaria hoje. A receita arrebanhada pelas cotas de TV é a que mais contribui para a liderança do Corinthians neste ranking. Em 2012, o clube recebeu R\$ 112 milhões com contratos do gênero. A vice-liderança na lista pertence ao Flamengo, que tem a sua marca avaliada em R\$ 792 milhões. Diferentemente do Corinthians, o Fla é líder entre torcedores de diferentes classes sociais do País. Sua participação entre os torcedores mais ricos, no entanto, diminuiu relativamente, enquanto a presença nos extratos mais pobres da sociedade cresceu, segundo a BDO. Fechando o pódio, o São Paulo aparece com a marca avaliada em R\$ 771 milhões. Em quarto está o Palmeiras, com R\$ 481,2 milhões. O primeiro time fora do eixo RioSão Paulo a figurar no ranking é o Inter, quinto colocado, com R\$ 392,9 milhões.” (Pelo 4ªno..., 2013).

Horizontes Antropológicos, Porto Alegre, ano 19, n. 40, p. 149-184, jul./dez. 2013 
de uma demanda histórica dos corintianos de ter um estádio mais condizente que abrigasse a massa torcedora. "Ganhar um estádio", tal como aparece correntemente disperso em muitas falas, tem mobilizado outros significados no constructo simbólico que define a forma de torcer denominada de corintianis$m o$, contrastando aos valores que fizeram dele um marco diacrítico entre os demais conjuntos torcedores pela cidade.

A argumentação geral aqui é a de que se as necessidades logísticas para a execução do megaevento na sede paulista obviamente não foram dissociadas das costuras políticas em níveis global e local, corriqueiramente anunciadas na mídia, produzindo discursos prós e contras o legado da copa, ${ }^{4}$ meu foco é perceber num nível ainda mais local alguns dos implícitos (Goldman, 1999) desse movimento no interior do sistema classificatório torcedor na medida em que pode oferecer algo novo no repertório simbólico de sua expressão e reatualização. Concretizada a promessa de um estádio o corintianismo pôs-se em movimento na direção de uma redefinição de seu estilo, a produzirflashes modernizantes numa forma de torcer que sempre se impôs pela fatura popular, tradicionalmente contendora, mas estigmatizada por seus adversários.

\section{Corintianismo como forma de torcer}

Formas ou estilos de torcer tratam das estilizações de práticas torcedoras em proximidade com outros agentes (policiais militares, promotoria pública, dirigentes esportivos, mídia especializada, políticos), instaurando regimes de alteridade que supõe adesões variadas dentro do universo do clubismo. Atualmente a figura político-jurídica do torcedor genérico, sem rosto e sem ritualizações, se eleva no plano do espaço público como problema, demanda, necessidade, solução, se pensarmos que no universo do consumo ganha cada vez mais importância a figura do torcedor consumidor como arrimo moral e legal da ordem esportiva distributiva da riqueza que aí se produz e acumula.

\footnotetext{
4 Damo (2012) nos adverte para a disputa pelo termo "legado", espécie de divisor de águas entre entusiastas e pessimistas em relação à realização dos megaeventos esportivos no Brasil. Seu texto traz uma radiografia interessante sobre os significados imbricados no descritor "legado": "Os promotores tendem a colocar no rótulo denominado de 'legado' um conjunto tão heteróclito e disparatado de elementos que o termo tornou-se arbitrário. Do ponto de vista do significado, legado há muito deixou de ser aquilo que de bom vai restar depois do término do evento para ser uma modalidade de significante flutuante, um termo que comporta tal quantidade de significações que já não consegue especificar o que quer que seja.” (Damo, 2012, p. 46).
}

Horizontes Antropológicos, Porto Alegre, ano 19, n. 40, p. 149-184, jul./dez. 2013 
Porém, assim como estilos de jogo, formas de torcer são tomadas por recombinações frequentes dentro de um repertório heteróclito (corporalidades, gestualidades, linguagens e categorias de acusação, estigmatizações e estereótipos, performances, mas também imagens, circunstâncias, objetos, coisas) que aderem às práticas torcedoras e delineiam fronteiras situacionais e combinatórias (Hannerz, 1997) mais ou menos visíveis e permanentes.

Guedes (2009) ao definir estilo de jogo, amparada em alguns autores (Bromberger, 1998; Damo 2007; Toledo, 2002) aponta para o processo altamente dependente e dinâmico de produção de narrativas e desempenhos que atualizam tais estilos de jogar, o que vale para as formas de torcer na medida em que também procuram adensar realizações estereotipadas e idealizadas de grupos torcedores distintos. Se o futebol moderno amparado no fenômeno dos megaeventos reivindica a presença universal do torcedor consumidor temos que atentar para as apropriações diferenciais constitutivas da complexa prática processual do torcer em níveis locais.

Ainda em relação aos estilos, segue a autora:

[...] não é absolutamente possível que um "estilo de jogo" determinado se realize continuamente em todos os desempenhos e eventos. Mas é altamente provável que a representação coletiva sobre um "estilo de jogo" se constitua nas lentes através das quais todos os desempenhos daquele time sejam avaliados, aplaudidos, criticados. (Guedes, 2009, p. 458).

Portanto, se há instabilidade nos estilos de jogar, combinação sempre posta à prova nas performances esportivas, na constituição de elencos competitivos, disciplinas táticas, manuseio das regras (Toledo, 2002), há movimento em relação aos estilos de torcer que buscam assumir formas específicas na medida em que mobilizam repertório e atributos à disposição desta ou daquela torcida. Mas é preciso advertir que entre os repertórios que definem formas de torcer e os agrupamentos torcedores não há relação unívoca e a distribuição (o que implica, portanto, trocas, apropriações de torcida para torcida, etc.) dos itens que compõem determinada forma pode variar ao longo de processos históricos específicos.

Sendo assim, "Corintiano, maloqueiro e sofredor, graças a Deus!" por muito tempo segue como bordão que confere síntese ao corintianismo, que faz de algumas faltas, evidentes estigmatizações de classe, sua maior qualidade 
distintiva. ${ }^{5}$ Sociologia nativa, tais faltas são tomadas como elogio à carência e à condição econômica subalterna e de classe que se impõe num misto de realismo e imaginário na relação com seus outros, historicamente são-paulinos e palmeirenses. Não há no cultivar dessas ditas faltas qualquer fatalismo sociológico, dado que a relação torcedora com essas supostas carências tem dinamizado, há décadas, uma peculiar forma de torcer reconhecidamente contendora, presente e fiel.

O fato novo é a aquisição do estádio, somado às recentes conquistas e títulos internacionais inéditos ${ }^{6}$ que reposicionaram o clube dentro do sistema classificatório clubístico. Agora, a vivência torcedora se vê diante de acontecimentos que se não diluem imediatamente a densidade e eficácia simbólica do tradicional bordão orientado pela inversão simbólica do estereótipo das carências ao menos o coloca num outro plano de relacionalidade que a própria fatura popular, sinal diacrítico dessa forma, tenta equacionar em meio às recentes transformações em curso.

O estádio consiste numa das peças de todo um constructo sociotécnico, para usar expressão simmeliana na conceituação de cidade (Simmel, 2005), cujo impacto nas formas do torcer pode trazer alguma luz para pensar os aspectos constitutivos dessa identificação entre indivíduos e clubes de futebol, mais apropriada analiticamente se tomada na chave maussiana da fabricação da pessoa. Portanto, o corintiano de ontem não é o mesmo corintiano de hoje, e esse processo contínuo de produção e distribuição criativa de práticas em busca de uma forma contrapõe-se às percepções mais essencializadas que partem das biografias pessoais na identificação clubística, ou das determinações sociológicas assentadas na descendência, que pressupõe o acento no familismo e na parentela como loci do parentesco esportivo.

Se a filiação clubística centraliza-se na vontade pessoal (estimulada a partir de inúmeras possibilidades) ou na herança futebolística familiar extensa,

\footnotetext{
Tais estigmatizações advêm tanto da origem popular do clube quanto das sucessivas administrações que por muito tempo se afastaram dos modelos ditos "profissionais" de gerenciamento esportivo, situação que se alterou no último decênio.

6 Lembrar que 2012 foi o ano em que o Sport Club Corinthians Paulista sagrou-se, pela primeira vez, campeão da Copa Libertadores e campeão no mundial interclubes no Japão, fatos que, embora valorizados tardiamente, foram muito comemorados, sobretudo porque outros clubes rivais os tomavam (e há tempos) como índice de especificidade identitária no jogo das alteridades torcedoras na formulação das formas de torcer.
}

Horizontes Antropológicos, Porto Alegre, ano 19, n. 40, p. 149-184, jul./dez. 2013 
o que parece mais interessante verificar é como tal filiação abre-se para experiências e estilos diversos à procura de uma forma que estabilize, creio, $o$ subjetivismo encerrado na ideia de paixão clubística. É nesse sentido que a construção do estádio se agrega ou se acomoda a uma forma específica, oferecendo um corpo edificado e concretude para um torcer que, sem estádio, tem vagado por espaços que não lhe pertencem. ${ }^{7}$

Porque do ponto de vista dos corintianos que promovem a visitação ao canteiro de obras há algo mais do que mera percepção instrumental na ideia de aquisição de um patrimônio edificado na medida em que reposicionam a construção do estádio numa "textura relacional" específica, conferindo ao estádio "uma participação sensível na vida social" (Barcelos Neto, 2008, p. 29). Dessa maneira, os torcedores têm pressuposto alguma internalidade (personitude) e intencionalidade a essa forma edificada, abrigando-a ao conjunto de relações que demarcam as fronteiras do corintianismo. Barcelos Neto (2008, p. 31) ao enunciar suas opções teóricas para tratar de um caso etnográfico específico oferece uma síntese da hipótese mais geral de autores como Gell, que "inter-relacionando casos etnográficos [diversos] torna saliente pelo menos uma semelhança central na sua teoria: 'seja no Ocidente moderno ou em tal ou tal ilha do Pacífico' [grupos sociais distintos] atribuem intenção e consciência aos objetos não viventes". ${ }^{8}$

Aproximo essa ampla ideia ao que Lagrou (2007, p. 50) afirmou em outro contexto etnográfico sobre os objetos que são feitos para "completar a ação dos corpos" e, nesse sentido, o estádio que ganha silhueta na paisagem de Itaquera tem revelado um bom indício da transformação da pessoa corintiana naquilo que concerne à incorporação de agentes materiais que efetuam e reatualizam a vontade torcedora. ${ }^{9}$

Há uma ideia comum partilhada por inúmeras torcidas que acompanham seus times nos próprios estádios de que estes seriam verdadeiros caldeirões e

\footnotetext{
7 O último movimento de tentativa de aquisição de um estádio antes do mais recente projeto exitoso em Itaquera foi a frustrada proposta de arrendar da prefeitura o estádio do Pacaembu, localizado no bairro nobre de mesmo nome, nas imediações da avenida Paulista. Proposta que esbarrou na bancada não corintiana na câmara dos vereadores, mas também nas controvérsias sobre a patrimonialização do referido estádio, além das limitações jurídicas de utilizá-lo como arena multiuso (para shows, por exemplo).

8 Experimentos e utilizações da problemática da agência dos objetos em contextos ocidentais e urbanos podem ser consultados, por exemplo, em Santos (2012).

9 Em relação à categoria vontade, consultar Buarque de Holanda (2010).
}

Horizontes Antropológicos, Porto Alegre, ano 19, n. 40, p. 149-184, jul./dez. 2013 
armadilhas para os adversários, colocados como instrumentos da performance torcedora. A novidade aqui entre os corintianos, percebida no fluxo de uma etnografia um tanto peculiar, como descreverei mais adiante, é que o estádio ganha status de pessoa ao mesmo tempo em que aparece como espécie de corpo que melhor abrigará o sentimento torcedor, daí a noção de forma se sustentar como percepção imanente (e não só transcendente) do torcer.

Por essa via de análise, o Itaquerão cresce, toma feição, se alimenta da emoção levada pelos torcedores que para lá se deslocam, interpela e interage com os operários e os setores técnicos e, por fim e ao cabo, mais do que servir como espaço inerte de aglomeração esportiva ou monumento arquitetônico, será definitivamente incorporado ao corinthianismo como valor moral, crê-se que torcerá e jogará em prol do clube.

Para além da forma arquitetônica como um caldeirão interessa percebê-lo como matéria não inerte, pois "impõe o modo como materiais de todos os tipos, com propriedades variadas e variáveis, são avivados pelas forças do cosmo, misturadas e fundidas umas às outras na geração de coisas [...]" (Ingold, 2012, p. 26), e nessa direção os torcedores contribuem para dar forma ao estádio que, por sua vez, dará forma ao corintianismo.

Mas não forma acabada como projeto de engenharia, de objeto a ser usado ou contemplado, mas agida no fluxo torcedor que antecede (ou impede) o final das obras. Inconclusa numa concepção simbólica, porque fabricada continuamente, sairão os engenheiros e a engenharia social e entrarão os torcedores com sua socialidade. Estádios "fabricam" torcedores, pois espacializam e multiplicam a emoção dos grandes espetáculos esportivos (Cleland, 2010; Curi, 2012), mas aqui interessa pensar, sobretudo, que torcedores também fabricam estádios no exato sentido que empresto ao termo forma de torcer, pois a edificação constitui um novo evento dentro do repertório manipulado pela experiência do corintianismo que acompanha, num nível sem precedentes, ao menos se comparado a outras experiências próximas na cidade de São Paulo, as obras em Itaquera.

Nascido de uma multialiança (pública e privada, interpessoalizada e politizada em várias esferas ${ }^{10}$ ), o estádio problematiza o referido bordão que se

${ }^{10} \mathrm{O}$ tema do favorecimento ao Corinthians vindo da relação com altas esferas da política nacional é reiteradamente noticiado nos meios de comunicação. Juca Kfouri (2012), ao comparar Corinthians e Palmeiras do ponto de vista administrativo, aponta para a singular relação: "Se o Corinthians foi outro que conheceu a humilhação da segunda divisão [...] é verdade que no Parque São Jorge as coisas evoluíram - não sem uma portentosa ajuda de Lula [...]."

Horizontes Antropológicos, Porto Alegre, ano 19, n. 40, p. 149-184, jul./dez. 2013 
sustentou tanto pela noção de falta, já mencionada, quanto por outro termo que também orientou por um bom tempo o discurso corintiano genérico, o quase na produção dessa forma de torcer.

O fatalismo do quase impactou os corintianos em intensidade variável, pois quase o time ganhava títulos importantes, quase o clube teve um estádio em várias oportunidades na costura política com sucessivas administrações municipais e, apesar da popularidade em território nacional, quase era uma marca firmada nacionalmente e reconhecida no exterior.

Conquistados os títulos reivindicados pelos torcedores, fortalecida a marca como patrimônio econômico, resta ao quase e à noção de sofrimento a ele incorporada, transformarem-se em quase lá, já que o estádio está quase pronto em função das demandas da Copa do Mundo, cujo impacto na redefinição dessa forma de torcer já se insinua na socialidade torcedora antes mesmo do término da obra e sua reificação em equipamento técnico, político e urbanístico.

\section{Por uma etnografia do "quase"}

Trato a etnografia que venho realizando nas imediações do canteiro de obras como uma quase etnografia que espero ser convertida numa etnografia do quase. Quase etnografia porque o tom linear e ad hoc imposto à narrativa, próxima ao de um caderno de campo, mercê das contingências que vivencio a cada ida a campo, ao sabor de uma cronologia e protocolos pouco sistemáticos impostos ao pesquisador despossuído de autoridade etnográfica (Cliffort, (2011), propõe revelar as pequenas surpresas e saliências capturadas por uma observação que, embora treinada alhures, foi entregue à deriva das situações pouco indutivas, expondo de imediato o texto e o próprio pesquisador aos princípios que em tese os desqualificariam, quais sejam, uma deliberada ausência de modelo explicativo ou busca de práticas metodológicas mais padronizadas, revelando assim uma hesitação em produzir grades classificatórias fechadas ou totalidades empíricas ou analíticas que garantam algum sucesso dessa empreitada.

A etnografia propriamente dita, que venho produzindo a cada visitação, mantém-se estrategicamente descosida e nesse sentido a chamo de "realista", porém absolvendo-a da crítica à etnografia realista feita a partir do modelo malinowskiano. Realista ao pé da letra porque menos redirecionada e encadeada a posteriori. A tentativa é de que os temas apareçam no frescor das 
relações do etnógrafo com os interlocutores, para desaparecerem no fluxo das transformações da própria obra. Num dia, participo de conversas e embates acalorados num grupo de torcedores, noutro dia o mesmo assunto desaparece porque não somente o grupo já não é mais o mesmo, como a própria obra "caminhou", mudou a perspectiva arquitetônica, a possibilidade de ser olhada como antes, produzindo outras dúvidas e especulações, possibilitando a recriação de outras falações a seu respeito ou a respeito de temas concernentes ao multiverso do futebol.

As visitações contrastam vivamente com o cronograma de execução imposto ao olhar leigo que percebe diante de seus olhos o andamento de um organograma técnico de engenharia infalível, e, no que concerne aos torcedores, é o olhar matizado pela propulsão do "quase lá" que se insinua. Numa manhã de 30 de junho de 2012 interpelei um torcedor que, rememorando sua primeira visita, disparou: "Quando vi lá de baixo subir a primeira grua, puxa, falei! Não é que vamos ter um estádio mesmo? Foi uma emoção do caralho.” É notável como a presença de uma única máquina, a grua, foi suficiente para que ele expressasse aquela materialidade ainda em fragmentos e sem forma definida do estádio como algo potencialmente construído, garantido pelo simbolismo de uma forma de torcer que projeta na arquitetura ou extrai dela ainda inconclusa a totalidade da expectativa torcedora.

Por isso não busco clímax ou ritualizações expressivas a serem recolhidas na observação. Salvo pelos ajuntamentos torcedores em churrascos promovidos pelas torcidas organizadas aos sábados em frente aos portões da construtora, a descrição tem seguido o andamento aparentemente caótico e desritualizado de um canteiro de obras para quem o vê de fora.

"Veja, nenhum acidente aconteceu na obra", exultou outro torcedor próximo a mim numa dessas idas a campo, ${ }^{11}$ fazendo um elogio à rotina e cotidianidade instauradas no ritmo do trabalho até aquele momento. Mesmo os comportamentos que se insinuam mais ritualizados nas beiradas do canteiro, como é o caso dos churrascos e outras comemorações, nada produzem, tal como sugere a leitura de Geiger (2008, p. 37) sobre o ritual do naven descrito por Bateson, necessariamente "acréscimos, inversões ou alterações drásticas", nem à obra nem ao comportamento torcedor que espera pelo estádio. Trata-se,

11 Numa das primeiras incursões, precisamente no dia 4 de fevereiro de 2012.

Horizontes Antropológicos, Porto Alegre, ano 19, n. 40, p. 149-184, jul./dez. 2013 
antes, de uma negociação da realidade (Velho, 1994, p. 21) onde o reconhecimento dos vários níveis de alteridade estabelecidos entre torcedores com os demais atores (engenheiros, turistas, operários, dirigentes, políticos, pesquisadores e todos outros que promovem visitações ao local) se acomoda aos interesses mais imediatos que preservam o andamento da edificação do estádio.

O fim da etnografia coincidirá com o fim da obra, dezembro de 2013, data de entrega oficial do estádio à cidade, e coincidirá também com o fim de parte do simbolismo que moldou a forma de torcer do corintianismo em torno do advérbio "quase".

Digo também que a descrição tem seguido necessariamente um andamento aparentemente caótico porque a saturação dos dados se revela num resultado que é menos condição imposta pela presença do observador do que ditado pelas circunstâncias de um fenômeno que, como acabei de dizer, tem data para findar, o que traz alguma peculiaridade à dinâmica etnográfica. Ademais, acompanhar quase de dentro um canteiro de obras não oferece ao etnógrafo oportunidades muito reiterativas, tais como os adensamentos rituais e outras ações formalizadas que definem formas relacionais mais estáveis e aparentemente mais adequadas à observação. Também não permite que dados sejam revisitados pela reobservação direta e ao final de tudo teremos ali na Itaquera corintiana outra configuração, outras socialidades em jogo, o jogo propriamente dito a ditar novas dinâmicas de uma forma de torcer mais acomodada ao espaço urbano modificado e impactado pela nova conformação do lugar.

A descrição etnográfica segue o fluxo das idas a campo, cronologicamente, mas realizada em sobressaltos um tanto arbitrários, respeitando o acaso no encontro com os quase interlocutores sem hierarquizá-los, sem buscar informantes-chave. Nesse sentido, o procedimento diverge do canônico método malinowskiano de perscrutar uma cultura fixada num lugar, dado que a própria noção de lugar que abrigaria um nativo encarcerado (Appadurai, $1988)^{12}$ evita tornar-se um lugar antropológico no sentido metodológico que Augé (1994) empresta ao termo, ou seja, como lugar seguro ou mesmo refúgio

12 “[...] os nativos são pessoas que são de certos lugares e que pertencem a esses lugares, mas também que eles são aqueles que estão de algum modo encarcerados, ou confinados, nos seus lugares. O que precisamos de examinar é essa atribuição, ou suposição, de encarceramento, aprisionamento ou confinamento." (Appadurai, 1988, p. 37, tradução minha). 
da prática antropológica a descortinar identidades, realidades homogêneas e regularidades. Semana a semana impõe-se à observação uma velocidade variada que acaba por relativizar os recursos do olhar treinado a buscar coerências, regularidades, paisagens fixas.

Afinal, o saber produzido aqui é certamente mais modesto que o descortinar de uma "cultura" se tomada no sentido clássico, mas também não estou diante de uma etnografia multissituada (Marcus, 1995). Permanecendo o mesmo espaço físico, é o lugar que se altera bruscamente, e nesse sentido a etnografia ganha uma característica peculiar e, portanto, não se trata tão somente de mobilidade espacial dos informantes, mas "mobilidade" ou transformação severa do próprio espaço físico a produzir muitos lugares. Lugares temporários de onde se pode ver e falar sobre a construção em meio às restrições impostas pela construtora e pela ocupação física de sua materialidade esparramada pelo terreno.

E, à medida que o estádio ganha forma, o corintianismo ganha nova substância simbólica ao incorporá-lo ao discurso e prática torcedora. Portanto, mudam os interlocutores e suas opiniões, mas o espaço físico também é continuamente remexido e, nesse contexto a postura do etnógrafo deve sempre modular essas condições de instabilidade na tentativa de produzir alguma exegese etnográfica do que está acontecendo diante de seus olhos. Não há aqui exatamente um ponto de vista a ser firmado dada a instabilidade entre forma e conteúdo, regras e práticas, sujeitos observados e observadores. É nessa direção que defino a etnografia como multitransformadora, pois ao incorporar a noção de transformação como pressuposto e condição da pesquisa passo a seguir uma sugestão vinda do fenômeno observado.

Tudo parece sob a égide da ação, da opinião ligeira e atirada para quem quiser capturá-la, fazendo dela mais um pedaço da grande narrativa que se tornou a construção do estádio. Vale observar os detalhes (de uma única viga que se ergue e é notada pelos torcedores mais atentos e assíduos que fazem dela outro tema de acalorada discussão), vale sentir a velocidade da mudança na paisagem.

"Agora que estamos ficando ricos tudo vai mudar" é uma frase que exemplifica, entre muitas assertivas reveladoras e cúmplices, a reorganização simbólica do corintianismo, mobilidade social simbólica, captada por essa etnografia que, no entanto, vai além da mera apreciação individual, uma vez que a visitação à obra é motivada por uma vontade que se impõe também como 
obrigação aos torcedores do clube. E fora de Itaquera frases como "ainda não fui ver o estádio, mas preciso ir" ditam o sentido moral de um dever para aqueles que se sentem em falta com o clubismo renovado pelo advento do estádio.

Há no entanto um horizonte compartilhado, pois a pecha de pesquisador bisbilhoteiro e à deriva, maneira jocosa de situar em contexto de pesquisa ainda pouco ambientado ou, como nesse caso, de acesso mais restrito, pode ser imposta também aos interlocutores, ou seja, aos torcedores que se entregam igualmente a essa atividade da especulação ao visitarem as obras. Portanto, trago para a etnografia o testemunho de torcedores em condições de observação mais adversas daqueles poucos agraciados pelas ações de marketing do clube e da empreiteira ou mesmo daqueles que pela força da organização coletiva e presença política no interior do Corinthians (como as torcidas organizadas) adentram um pouco mais ao canteiro de obras e alcançam o mirante oficial de visitação:

A construção da casa própria deixou de ser um sonho para o Timão. Cinco felizardos tiveram a oportunidade de prestigiar, nesta quarta-feira (30), a festa de comemoração de um ano do início das obras da Arena Corinthians. Eles venceram um Concurso Cultural feito no site oficial do Clube. Em Itaquera, Rodrigo Cororato, Sarah Reis, Leonardo Boragan, Carlos Henrique Soares e Letícia Gomes Alves acompanharam a coletiva de imprensa com o presidente Mário Gobbi e o eterno ídolo da Fiel, Basílio. Os vencedores que representaram a República comeram o bolo, tiraram fotos e foram até o mirante, local com a visão mais privilegiada da obra. (Arena Corinthians..., 2012).

A pressa imposta pelo calendário oficial das obras, feito e refeito sob as pressões políticas e austeridade discursiva em nome dos interesses da FIFA, as negociações e entraves de toda monta, que envolveram a decisão e em favor de tal projeto visando a Copa do Mundo de 2014, se coadunam com os outros motivos incubados aos anseios e pressa dos torcedores por um estádio, por uma casa para amplificar e materializar as potencialidades do corintianismo. O estádio é como a contratação de um grande jogador que, em treinamento, espera por jogar.

Esse também parece ser um bom momento de observação dos significados políticos que recobrem o ato de torcer ao deslocar torcedores das arquibancadas para as quase arquibancadas que se erguem na paisagem da construção. É preciso ver para crer, fiscalizar, mas, sobretudo, falar sobre a obra e falar 
com ela. Falar é garantir que ela vá pra frente, que ganhe vitalidade, pois se trata de um recurso simbólico de agenciamento das coisas e do lugar, fala-se da viga de concreto, mas de tantas outras coisas, da casa de máquinas, dos pedaços de arquibancadas que tomam forma contínua, das gruas, do futuro gramado que não deveria ser verde para não lembrar as cores ostentadas pelo arqui-inimigo Palmeiras, como se essas coisas e objetos fossem dotados de índice de agência no fluxo das rivalidades espalhadas pela socialidade.

Outro dado saliente é o registro imagético que torcedores fazem da obra, e embora imagens e registros fílmicos sobre a construção apareçam abundantemente na mídia, facilmente capturados em downloads na rede, o registro pessoal passa a ser fundamental para comprovar que estiveram lá, e nesse sentido nada substitui a presença física. Reproduzo abaixo fragmentos do caderno de campo.

Hoje (4 de junho de 2012) o dia foi de calmaria e a peregrinação de torcedores praticamente inexistente ou mais esparsa, porém minha insistência valeu pela presença de um único torcedor que chamou a atenção porque tentei quase em vão interpelá-lo, sem muito sucesso. Era um rapaz da cidade interiorana de Jundiaí, e disse que aquela era a primeira vez que estava ali e dada sua pressa, pois passava pela cidade a trabalho, ou motivado pelas perguntas inoportunas que fazia a ele, mal parou para conversar e compulsivamente passou a tirar fotos com o celular porque "precisava", e fez isso durante uns ininterruptos 10 minutos. Lancei mão como artifício pra puxar conversa da sugestão de um ou outro lugar cuja tomada panorâmica do cenário poderia capturar melhor as imagens da construção.

Exceção das crianças e outros tantos idosos quase não há torcedores que deixam de registrar a evolução das obras e quem não vi com uma câmera me disse que já havia tirado muitas fotos em outras oportunidades. "Isso vai valer muito", para lembrar a fala de outro torcedor. As imagens são fundamentais não somente como testemunho visual, afinal, estão à disposição em muitos sites, capturadas por profissionais em tomadas mais privilegiadas e disponibilizadas em blogs e plataformas virtuais, ${ }^{13}$ mas são continuamente tiradas, sobretudo porque

13 “O site Arena Timão ao vivo foi criado para o acompanhamento da construção do futuro estádio do Corinthians desde o começo, Pedrinho (idealizador) queria que todos os corinthianos mesmo estando de longe pudessem acompanhar a construção do estádio. Foi então que surgiu a ideia de instalar uma câmera no alto de sua casa, privilegiado por morar em um local com ótima visão da obra, resolveu instalar uma câmera para acompanhar 24 horas por dia o desenvolvimento da construção." (História do site, 2011).

Horizontes Antropológicos, Porto Alegre, ano 19, n. 40, p. 149-184, jul./dez. 2013 
acionam o testemunho pessoal, o dilema compartilhado com o antropólogo da necessidade do "estar lá", o frescor da copresença como garantia e necessidade em transformar um lugar caótico, um não lugar em lugar antropológico (Augé, 1994). Nesse sentido ali também somos todos nativos, ou melhor, assim como os torcedores evitam a pecha de turistas, pois estão investidos de uma obrigação, atualizando uma forma de torcer, vale para o observador se afastar da condição de mero visitante, impondo à visitação um conhecimento que se quer produzir sobre o lugar.

Sigamos mais um pouco o relato desse dia em campo:

Dada a escassez de torcedores resolvi então circular mais perto dos portões que dão acesso ao interior do canteiro de obras, sempre, é claro, do lado de fora, ou quase dentro, de qualquer modo sempre muito próximo ao burburinho do entra $\mathrm{e}$ sai de operários. Chama atenção nesse dia a pouca presença de ambulantes a incrementar algum comércio em torno do vai e vem ali estabelecido, que se soma ao do portão do terminal do metrô Itaquera, posicionado em frente às obras. Não há bares, botecos ou ambulantes e o estabelecimento mais próximo é o shopping, onde alguns poucos trabalhadores em horário de almoço pareciam se aventurar. Ao chegar passei por alguns deles que, solitariamente se encaminhavam lá para baixo na direção do Shopping Metrô Itaquera. Mas nesse dia algum comércio despertou de maneira muito discreta e diria mesmo cautelosa. Antes de abordar as vendedoras de tênis e perfumes (perfume do timão, tal como eram chamados por aqueles que se aglomeravam em torno do carro das vendedoras) recolhi do chão uma luva abandonada por algum trabalhador no meio-fio. Fiquei a pensar se para além das imagens capturadas por centenas de torcedores outros objetos não poderiam ser transformados em souvenires, lembranças e testemunhos silenciosos a compor a memória da construção. Recolhi a luva...

Em se tratando de uma etnografia de coisas que se perderão, lugares que desaparecerão, de deslocamentos contínuos de pessoas e maquinário, vigas de concreto, aterros, as visitações têm constituído um conjunto de situações efêmeras, porém articuladas às dos torcedores que para lá se deslocam a sós ou em grupos ou quase grupos com a finalidade de "fiscalizar a obra".

Portanto, no exercício etnográfico há também um quase que adquire potência metodológica que retroalimenta a relação entre pesquisador e torcedores, pois esses que para lá afluem, alguns quase que semanalmente, para dar uma espiada "como vão as coisas", também flertam com o "quase" tomado como categoria de sentido e forma relacional, pois quase estão no estádio 
ainda em construção, quase têm acesso às suas dependências, quase produzem ali uma socialidade mais duradoura com o entorno, quase tomam para si os destinos do clube, quase compreendem a engenharia e a tecnologia "alemã", como escutei de um torcedor, implementada naquela monumental obra de engenharia, quase já podem, por fim, devolver anos e anos de pilhérias aos torcedores rivais que jocosamente ironizaram as sucessivas tentativas e promessas não cumpridas do Corinthians de ter um estádio para sua torcida.

Engenharia convertida em engenharia emocional pelos próprios torcedores, a etnografia pode servir de testemunho quase fotográfico de um momento efêmero onde espaço e lugar, somados à necessidade urbanística de remodelar todo o entorno do estádio, vão impondo uma nova nucleação estética e afetiva ao bairro, por extensão à zona leste e à cidade, deslocando patrocinadores, movimentando capital e o próprio Estado para a região, mas também equacionando a emoção esportiva dos tradicionais espaços em torno das noções de "centro" e "periferia".

\section{0 estádio como "coisa"}

O estádio tem sido comumente chamado na mídia e pelos torcedores de casa,${ }^{14}$ tomado aqui menos como locus produtor de parentesco esportivo e mais como redefinidor de uma forma de torcer. ${ }^{15}$ A construção interage, modifica, aciona e vaza criativamente as vontades do corintianismo. Também é tomado como mais uma pessoa corintiana, ou um supertorcedor ou superjogador (mas nunca um superdirigente ou supercartola, por exemplo), que nasce dos imperativos de uma vontade simbólica que o aloca no interior do

\footnotetext{
14 Por casa Lévi-Strauss (2004, p. 23) compreende "em primeiro lugar, uma pessoa moral; em seguida, detentora de um domínio constituído por bens materiais e imateriais; e que, enfim, se perpetua, ao transmitir seu nome, sua fortuna e seus títulos em linha direta ou fictícia, considerada legítima como única condição - que essa continuidade possa se exprimir na linguagem do parentesco ou da aliança e, na maior parte das vezes, das duas juntas".

15 Fato amplamente corroborado pela imprensa: "A cada dia que passa a Fiel está vendo o sonho da casa própria se tornar realidade. Arena Corinthians caminha em ritmo acelerado para receber a abertura da Copa do Mundo de 2014 em um projeto que já conquistou o VIII Grande Prêmio de arquitetura corporativa no ano passado e que tem como principal aspecto conciliar simplicidade das formas com os anseios do corinthiano. 'A primeira ideia é que o estádio servisse à torcida, que ajudasse ao time ganhar jogos. Então eu quis botar a torcida dentro do campo para empurrar a equipe', conta Anibal Coutinho, idealizador do projeto." (Leite; Favero, 2012).
}

Horizontes Antropológicos, Porto Alegre, ano 19, n. 40, p. 149-184, jul./dez. 2013 
corintianismo de modo singular e menos instrumental ou material que a categoria casa, se tomada como propriedade. A propósito, o estádio do arquirrival Palmeiras, à mesma época sendo reconstruído num bairro urbanisticamente consolidado e de impacto gentrificado como a Pompeia, recebe esse caráter mais instrumental. Denominado provisoriamente de Arena, ${ }^{16}$ já está reificado como mais um equipamento esportivo da cidade e, ao contrário do que ocorre no Itaquerão, os palmeirenses assistem mais passivamente às obras se consumarem na paisagem. Os impedimentos burocráticos e técnicos para a visitação expõem uma materialidade amorfa e o estádio só ganhará "vida", de fato, quando inaugurado.

Estendendo as observações de Ingold para o Itaquerão, temos que

assim concebida, a coisa tem o caráter não de uma entidade fechada para o exterior, que se situa no e contra o mundo, mas de um nó cujos fios constituintes, longe de estarem nele contidos, deixam rastros e são capturados por outros fios noutros nós. Numa palavra, as coisas vazam, sempre transbordando das superfícies que se formam temporariamente em torno delas. (Ingold, 2012, p. 29, grifo do autor). ${ }^{17}$

E assim como o engenheiro responsável é corintiano doente, confiam os torcedores com quem falei, tudo usado e disponibilizado na obra é, de alguma forma, corintianizado e passa a dizer algo sobre o corintianismo. Torcedores falam, mas as coisas também, numa interlocução que espalha e multiplica ainda mais os corintianos do lugar, e a massa torcedora encontra sua forma concreta na argamassa a moldar e dar consistência às estruturas. Tudo, nesse sentido, é Corinthians. Tudo, menos a totalidade dos trabalhadores.

16 “O Palmeiras e a Allianz vão revelar no dia 6 de junho [de 2013] o novo nome da Arena Palestra baseado numa enquete entre torcedores. Especula-se que Allianz Parque foi o nome de batismo mais votado nas votações pelas redes sociais e pelo site da nova arena." (Allianz Parque..., 2013).

17 "A casa real é uma reunião de vidas, e habitá-la é se juntar à reunião - ou, nos termos de Heidegger (1971), participar com a coisa na sua coisificação. Como explica Juhani Pallasmaa (1996), nossas experiências arquitetônicas mais fundamentais são verbais e não nominais. Elas consistem não em encontros com objetos - a fachada, a padieira da porta, a janela e a lareira - mas em atos de se aproximar e entrar, olhar para dentro ou para fora, absorver o calor da lareira (Pallasmaa, 1996, p. 45). Enquanto moradores, nós experimentamos a casa não como objeto, mas como coisa." (Ingold, 2012, p. 30-31).

Horizontes Antropológicos, Porto Alegre, ano 19, n. 40, p. 149-184, jul./dez. 2013 
Porque esses precisam, de fato, de maior vigilância, pois muitos sabidamente torcem para outros times. Os trabalhadores instauram no interior da obra uma fissura a comprometer a resistência dos materiais e a argamassa simbólica. Tolerados, mas vigiados: "Vê aí se os caras estão fazendo direitinho, fica de olho", grita um torcedor para que um trabalhador reconhecidamente corintiano vigie alguns outros. Ou como ouvi de um grupo de crianças no primeiro dia de pesquisa em frente ao portão 2 da obra dispararem para dois trabalhadores que estavam provavelmente e pelo horário na hora do almoço: "Vai Corinthians, vamos trabalhar!"

Não é raro nesse contexto encontrar trabalhadores descrentes ou incrédulos diante da devoção torcedora. Muitos até mesmo ironizam os pedidos insistentes para que tragam do interior da obra alguns souvenires, especificamente terra, muitas vezes vendida ali no burburinho do portão: "O cara pede que eu vá buscar terra lá onde será o gramado, eu pego daqui perto mesmo e o cara fica contente"; "uma moça ligou pra mãe e disse que estava na terra santa, imagina falar uma coisa dessas", disparam alguns trabalhadores mais incrédulos. Alteridade próxima, portanto perigosa, os trabalhadores seguem as determinações técnicas e as especificidades da engenharia, às vezes burladas pelo contato frequente com torcedores que os interpelam e os investigam no jogo contrastivo da socialidade torcedora.

Os regionalismos ali aglutinados na origem social e geográfica desses trabalhadore ${ }^{18}$ produzem os efeitos de uma totalidade inconclusa. Mesmo a bandeira brasileira, signo totalizador por excelência do jogo entre nações que será encenado à exaustão por ocasião do megaevento aparece ostentada timidamente numa ou noutra escavadeira e o sentido da nacionalidade emprestado ao fato da copa parece momentaneamente englobado pelo corintianismo sempre à espreita e vigilante. Desse ponto de vista observamos aqui um efeito importante do megaevento na medida em que rompe fronteiras nacionais, colocando a noção

${ }^{18}$ Na reportagem intitulada "Aqui tem um bando de guerreiros" da revista Brasileiros, número 56, lê-se: "O Programa Acreditar, da Odebrecht, tratou de dar cor local à mão de obra: 300 operários moram ali na Zona Leste. [...] Mas o sotaque que prevalece - '98\% dos casos', calcula o engenheiro Frederico Barbosa, gerente de produção - é 'de Minas para cima'. A diáspora nordestina, mesmo aquela que se abriga em São Paulo há anos e décadas, emoldura o retrato fiel da nossa diversidade. Se a gente conseguisse precisar, ponto por ponto, cada uma das cidades de onde procedem os trabalhadores do Itaquerão seria como desenhar o mapa do Brasil. O que desmente uma das lendas acerca da obra: a de que aquilo ali é um ninho exclusivo de corintianos fanáticos. De Norte a Sul, tem time para todos os gostos." (Oliveira; Beirão, 2012).

Horizontes Antropológicos, Porto Alegre, ano 19, n. 40, p. 149-184, jul./dez. 2013 
de identidade em perspectiva e expondo um país sem fraturas para fora de suas fronteiras. Entretanto, essa suposta coesão não deixa de secretar e dar vazão às novas formas de localismos, no caso, o clubístico incorporado no corintianismo, que se apresenta como contradiscurso ao global e ao ufanismo oficial.

\section{Uma obra, muitos estádios}

“Ali [eu pergunto onde] perto [mais exatamente onde abriga o relógio institucional da prefeitura e do governo do Estado que conta o andamento das obras] vão fazer uma estátua de São Jorge do tamanho daquela do padre Cícero." Procuro a estátua na minha imaginação, todavia, obviamente, nem se precisa dizer que ela não consta do projeto original do estádio.

Se a pressa dita o ritmo do trabalho de campo, compactua porém com a socialidade presente no simbolismo que recobre a demanda por um estádio acalentada há décadas pelos corintianos. Nesse sentido todos têm pressa ou se imprime alguma pressa, sejam aos operários, às máquinas, à ansiedade torcedora em registrar o que está acontecendo, ao antropólogo em buscar a dimensão inventiva emanada desse processo finito, ao Comitê Organizador Local da Copa do Mundo (COL) sempre pressionado pela FIFA, maior beneficiária econômica do megaevento.

Ao marcar edificadamente o fenecimento do simbolismo do "quase" impõe-se a pressa como mecanismo político de transformação simbólica de uma forma de torcer.

O estádio sendo construído é a novidade, as falações a respeito dele, no entanto, acumulam décadas de especulações de toda ordem e todos que aparecem por ali creem saber com maior ou menor acurácia algo sobre ele, sobre o maquinário todo que se impõe pelos canteiros que aos poucos vai materializando uma demanda ditada há muito pelo simbolismo do "quase", viabilizando interesses políticos e econômicos, sentimentos e pertencimentos, tudo ao zunir e ranger das máquinas e seus trabalhadores compenetrados.

Mas o verdadeiro estádio, aquele visível, dos espaços racionalizados e estratificados, das áreas VIPs e das pessoas com "hospitalidade" 19 é o que se

19 "Hospitalidade" é um termo que pode ser lido nos sites oficiais do Comitê Paulista para a copa na dinâmica de venda dos pacotes turísticos. 
ergue na paisagem de Itaquera, o estádio alienado aos construtores, de posse do clube, vigiado pela mídia e pelo Ministério Público, acalentado por dirigentes e futuros torcedores assistentes que para lá serão convergidos e reconvertidos dentro do corintianismo renovado.

Já os outros estádios evocados nas falas entrecortadas dos visitantes não convidados da obra, e que em parte sumirão logo que o verdadeiro assumir seu lugar político, espalharão seu simbolismo para outros recantos e canteiros de uma socialidade torcedora que, embora deixada na memória de quem lá esteve diante da monumentalidade que se ergue, ficará eternizada nas relações de outra ordem, mais ritualísticas, competitivas, reificações do comportamento de massa em shows e espetáculos esportivos.

Itaquera será por um curto período o epicentro da Copa do Mundo, mas se perpetuará como nova centralidade esportiva na cidade, insistentemente tomada como periférica pelos detratores do estádio, cuja lógica dos interesses políticos e esportivos ficou bem expressa nos embates tanto entre dirigentes rivais com também nos debates no interior da Câmara Municipal de São Paulo quando da votação das isenções fiscais que viabilizaram o início das obras (29 de junho de 2011). ${ }^{20}$

Sendo assim, há em Itaquera o estádio dos políticos, o dos torcedores em geral, o da mídia, o da FIFA, ou mesmo aquele dos dirigentes dos clubes e, por fim, o dos próprios torcedores corintianos. Amalgamados à argamassa que dá liga às estruturas permanentes de concreto todos esses interesses e expectativas múltiplas e obviamente conflitantes ficarão perpetuados no estádio como trabalho morto, mas revivido na lógica simbólica num processo de desreificação ditado pela socialidade torcedora que fará o estádio torcer, chorar ou sorrir.

Nesse novo ciclo de projetos de um estádio corintiano, este que finalmente toma forma nasceu em função do tumultuado processo de escolha da sede paulista para a Copa do Mundo, levado por uma conjuntura que se mostrou favorável e alternativa política, técnica e urbanística diante de outras

20 A data formal de início das obras foi 30 de maio de 2011, portanto, muito próxima do desfecho da votação do pacote de isenção fiscal na Câmara de São Paulo. Não trato aqui, por razões de espaço, dessas negociações políticas. 
apresentadas, tais como o malfadada tentativa de fazer do estádio do Morumbi, de propriedade do São Paulo Futebol Clube, ${ }^{21}$ a sede paulista.

Nessa direção é possível consultar no meio jornalístico no ano de 2010 aqueles que fizeram um resumo dos indícios que precipitaram na escolha do terreno de Itaquera como o lugar da copa. À época do texto que segue, no entanto, ainda cabia especular sobre outro local que, segundo a apreciação do jornalista e confirmada logo mais, desbancaria de vez o estádio Cícero Pompeu de Toledo, o Morumbi, como, até então, única alternativa viável de sediar a porção paulista do megaevento:

Enquanto a Fifa não se define sobre o aproveitamento do Morumbi na Copa/14, surge a possibilidade concreta de um novo estádio de futebol para o estado de São Paulo: a Arena Multiuso de Pirituba, na Zona Norte da capital, próximo a Rodovia dos Bandeirantes. A ideia é construí-la por meio de uma PPP (Parceria Público Privada), com capacidade para 40 mil torcedores e um investimento de $\mathrm{R}$ \$320 milhões. Por trás de toda essa polêmica, suspeita-se de uma manobra de Andres Sanchez [então presidente do clube], que estaria interessado em adotar, após a Copa, essa nova praça de esportes como a "casa do Corinthians". Indícios para alimentar essa suspeita são muitos. A saber: O Corinthians não tem estádio e vem usando o Pacaembu, cuja capacidade é pequena para acomodar a sua grande torcida. O Corinthians rejeita jogos no Morumbi, por conta de rusgas entre [então presidentes] Andres Sanches e Juvenal Juvêncio. Andres Sanchez é amigo do [então] presidente Lula que abriu as portas do Governo Federal para ele. Essa PPP só sai do papel se Lula estiver de acordo. O presidente Lula é corinthiano desde criancinha. Andres Sanches é aliado de Ricardo Teixeira, presidente da CBF. Andres Sanches era candidato a vice do Clube dos 13, na chapa liderada por Kleber Leite (apadrinhado de Teixeira). Juvenal Juvêncio [presidente do São Paulo Futebol Clube] é declaradamente contra Ricardo Teixeira. Juvenal Juvêncio votou em Fábio Koff para a presidência do Clube dos 13. Jerome Valcke, secretário-geral da Fifa, chega amanhã a São Paulo. Jerome Valcke nunca gostou do projeto de reforma do Morumbi. Jerome Valcke

${ }^{21}$ Comunicado oficial da FIFA sobre a exclusão do Morumbi: "Não foram entregues ao Comitê Organizador Local da Copa do Mundo 2014 (COL), por parte do Comitê da Cidade de São Paulo, as garantias financeiras referentes ao projeto do Estádio do Morumbi aprovado pelo COL/FIFA no dia 14 de maio de 2010. O Comitê da Cidade de São Paulo enviou ao COL um sexto projeto, que não será examinado. Sendo assim, fica excluído do projeto da Copa do Mundo de 2014 o Estádio Cícero Pompeu de Toledo, o Morumbi. A FIFA e o COL estão à disposição da cidade de São Paulo para futuras discussões." (Oficial..., 2010). 
será blindado nessa visita ao nosso País, para não dar entrevistas e não comprometer futuras negociações. Jerome Valcke será acompanhado em todos os seus passos em SP e Brasília por Ricardo Teixeira e Andres Sanches. Jerome Valcke é amigo íntimo de Ricardo Teixeira. Já foi seu hóspede em dois Reveillons no Rio de Janeiro. Por fim, já existe um projeto na Secretaria de Esportes de SP que prevê a construção de um novo estádio para a Copa/14 e para as Olimpíadas/16. (Marcondes Brito, 2010).

Alguns meses depois, Juvenal Juvêncio, citado presidente do São Paulo Futebol Clube, numa entrevista concedida às rádios e televisões sobre as propostas oferecidas diante do descarte do Morumbi como possibilidade de sediar a Copa do Mundo, voltava a criticar as alternativas que colocariam o projeto corintiano de estádio no caminho dos interesses da FIFA. Infelizmente o leitor não pode aqui atentar para a manifestação em off das risadas difusas na entrevista coletiva, que deixam alguma suspeita de consentimento com aquilo que foi dito de modo irônico pelo presidente são-paulino:

Você vai fazer em Pirituba, digamos, como é que você chega em Pirituba, como é que é o negócio do hotel, como é que é o negócio do transporte, como é que é o negócio do metrô, com é que é o negócio hospitalar, se o sujeito lesiona lá, o Blatter, como é que ele vai ser socorrido lá [...] não é diferente de outros locais, citemos, por exemplo Itaquera, você pra chegar lá precisa chamar o corpo de bombeiros [risos incontidos], se você pega a Angela Merkel da Ingla... da Alemanha e manda ela ir lá, ela não chega, e se ela precisar sair, também não sai, isso é um fato... você não tem como fazer isso. ${ }^{22}$

O estádio, então, opera deslocamentos simbólicos nas relações políticas que incidem nas representações urbanísticas impostas à cidade e aos lugares de ocupação do futebol profissional nesses espaços, fenômenos inextrincáveis relacionados à dinâmica política de gestão da metrópole paulistana, tensionada, como vimos mais acima, pelas relações pouco amistosas entre dirigentes de clubes rivais e políticos da municipalidade compromissados senão com o jogo instável da política partidária, ao menos com o jogo estável das rivalidades clubísticas.

22 Programa Jogo Aberto, Rede Bandeirantes, 10 de outubro de 2010 (cf. https://www.youtube.com/ watch? $\mathrm{v}=\mathrm{o} 0 \mathrm{XxSyN7OYo)}$. 
Rumores de retaliação da chamada bancada corintiana frente aos entraves que são- paulinos impuseram às suas demandas na Câmara Municipal são reavivadas em outras questões de natureza urbana e que, mais uma vez, dizem respeito ao modo como tais clubes ocupam de modo privilegiado os espaços da cidade. O suposto jogo parlamentar da política como exercício e negociação com "o outro", valor que se quer universalizado ou democrático nesse âmbito, é posto à prova pela pouca dispersão das inimizades da grade classificatória futebolística, e que em momentos de intensa especulação em torno da copa alcança sua eficácia e lugar na política, prolongando-se sobre temas e querelas amortecidas num pretenso jogo pelos "interesses comuns" da cidade:

Vereadores ligados a tal "bancada corinthiana" na Câmara, estão em mãos com um relatório que pretendem utilizar para abreviar a utilização dos CTs localizados na Barra Funda, concedidos pela Prefeitura à Palmeiras e São Paulo. Sabe-se lá com que interesse. Descobriram que a concessão do Tricolor é válida até 2023, e a palmeirense finaliza apenas em 2028. A intenção é que obriguem os clubes a desocupar a área até 2014. De que maneira? Os documentos, em posse dos políticos, dizem que as contrapartidas, necessárias para que o acordo seja mantido, não foram realizadas ou, em alguns casos, quando iniciadas, não obedeceram ao que havia sido proposto. O São Paulo teria que ceder as instalações do CT para alunos da rede municipal de ensino através da Secretaria de Educação, embora não exista especificação de como e quando isso deveria ser feito. Já no caso do Palmeiras, a obrigação era a de construir e ceder um centro poliesportivo aos alunos, fato que, segundo os vereadores, não foi realizado. Será uma briga de foice entre "zelosos" políticos que, aparentemente, não encontraram problemas na concessão de dinheiro público e terreno no bairro de Itaquera, local em que a grande maioria deles visitou apenas para tirar fotos, e dois dos maiores clubes do Brasil, que terão que se defender juridicamente das acusações. (Vereadores..., 2012).

\section{Ritual e evento}

Venho discutindo megaevento esportivo (Toledo, 2012b) a partir da perspectiva de que evento não sinonimiza ou aponta diretamente para o conceito de ritual, conceito este que balizou por um bom tempo toda uma bibliografia importante sobre a relação entre futebol e sociedade brasileira desde Universo do futebol (DaMatta et al., 1982).

Horizontes Antropológicos, Porto Alegre, ano 19, n. 40, p. 149-184, jul./dez. 2013 
Embora um ritual possa ser tomado como evento singular, alocá-lo na análise discriminando-o é explicitar alguma assimetria produtiva e decisão metodológica. A Copa do Mundo como um evento é tomada do ponto de vista dos observados, ou parte deles, e, portanto, uma categoria nativa hiperbolizada pelo prefixo "mega". Já ritual está compromissado com o olhar do observador, ou seja, com a tradição antropológica assentada na noção de dramatização que tomaria o futebol como catalisador de ritualizações sociais da identidade.

Minha hipótese é a de que o advento da Copa do Mundo repactuaria metodologicamente essa equação, aproximando ou embaralhando observadores e observados, como afirmei mais acima, promovendo uma inversão entre categoria nativa e analítica, ou, em última análise, promovendo a categoria nativa evento à instância de análise ou ainda as misturando no fluxo da etnografia.

Copa do Mundo como ritual, um ritual esportivo a bem dizer, produziu e foi produto da noção de identidade que se projetava, sobretudo, "para dentro", para os confins da nação a qualificar reificações simbólicas de que somos competentes a produzir uma expertise futebolística delineada pelas fronteiras territoriais e simbólicas que definiam uma dada "cultura" e sua consequente "cultura esportiva". O Brasil jogava diferente, tínhamos alguns atributos mobilizados pela nossa essência e particularidade como nação, cultivadas pela noção de criatividade. Mas também,

em certo sentido, a copa continua sendo o que sempre foi desde 1930, quando foi disputada pela primeira vez no Uruguai: uma competição entre equipes de futebol que representam Estados nações. Justamente por envolver representações nacionalistas, a copa possui um forte componente político, mas este é mais relacionado aos afetos do que à diplomacia convencional. (Damo, 2012, p. 44).

E ampliando para o contexto internacional parece que as noções de cultura e de ritual esportivo implicaram por um bom tempo também a ideia de "segredo" a animar a sociopolítica esportiva no resguardo da criatividade, quer dizer, segredo ritual, segredo no uso e manuseio de técnicas, segredo dos especialistas na preparação de atletas, no uso das substâncias e da tecnologia, segredos industriais, mas também estéticos, políticos e econômicos, numa palavra, simbólicos.

A noção culturalizada de identidade que deteve a de segredo como catalisadora dessa sociopolítica esportiva produziu por um bom tempo as várias 
maneiras de vivenciar uma Copa do Mundo por intermédio do jeito, da essência esportiva de um povo, de um país, expondo contrastivamente esse jogo de nações através dos esportes e aí a noção de ritual como espécie de sacralização (universalização) do jogo ficou plasmada e ainda prevalece em boa parte do imaginário brasileiro acalentando uma dinâmica identitária. ${ }^{23}$ Não creio ser irrelevante (para além daquilo que se define por má cultura administrativa dos recursos no país) pensar que essa disjunção semântica entre evento e ritual também participe das corriqueiras explicações vindas de muitos lugares a respeito dos atrasos das obras e toda sorte de incertezas que pairou por um bom tempo a viabilidade da copa no Brasil. Paralisadas pela concepção de tempo ritual a praticidade do organograma de um evento se depara com os impasses administrativos e de execução das obras de mobilidade julgadas necessárias.

Não obstante é curioso como a sociopolítica esportiva hoje é repertoriada não tanto pela noção de sagrado, que se aproxima da noção de jogo desde o clássico de Huizinga (1993) publicado em 1939, fato ainda notado entre os torcedores que acompanho em Itaquera, mas por outras noções amparadas numa ampla discursividade tecnicista, de engenharia, ditada pelos "sistemas perito" (Giddens, 1991), onde repousaria a confiança, estabilidade e a competência. ${ }^{24} \mathrm{O}$ impacto das obras do Itaquerão ao menos no imaginário daqueles torcedores mais interessados é revelador dessa ressemantização que segue definindo a dinâmica específica desse megaevento esportivo a produzir suas versões pelas cidades-sedes do país. ${ }^{25}$ Amparado por um bom tempo no sagrado esportivizado hoje o corintianismo tem que conviver com a materialidade de um sucesso laico que se transformou com a renovação gerencial de seus quadros administrativos e com a aquisição do estádio, pedra de toque da nova política clubística ali instaurada.

Megaevento, tomado aqui a partir da partícula evento, insinua um novo simbolismo, produz outra serialidade de fenômenos capturada num tempo histórico muito distinto. Megaevento, mais do que um momento pontual inserido

\footnotetext{
${ }^{23}$ É significativo o engajamento de muitos pesquisadores que se debruçaram sobre o tema futebol a partir da segunda metade dos anos 1990, o que acabou por matizar bastante os limites desse "nacional", trazendo a perspectiva local como contraponto argumentativo e enriquecedor de um multiverso futebolístico no Brasil, matizando a equação futebol-identidade nacional.

24 “'...] sistemas de excelência técnica ou competência profissional que organizam grandes áreas dos ambientes material e social em que vivemos hoje" (Giddens, 1991, p. 35).

25 Para o caso específico de Porto Alegre, ver Damo (2011).
} 
no calendário esportivo internacional, condiz com a ideia de um processo complexo de produção e ao mesmo tempo destruição de riqueza, quer material, quer simbólica, desestabilizando "velhas" identidades e produzindo um fluxo de informações que, se não obliterou totalmente a noção simbólica de segredo atrelada à noção culturalista de identidade nacional, ao menos a recolocou no concerto das novas relações dentro da paisagem esportiva internacional.

De qualquer maneira não se trata mais de ocultar uma "cultura esportiva" para que ninguém a aproprie, para que suas qualidades não se alienem para outrem, mas justamente ao contrário, que os fluxos se atualizem, que as benesses do discurso em torno da competência sejam em princípio distribuídas, alcançando inclusive a opinião torcedora. Assim, nos segredos da criatividade cultural e esportiva, hoje comprimidos pela atualização da competência, o hoje vira pretérito em instantes, jogadores aparecem, se notabilizam e desaparecem rapidamente, a produção incessante de pés de obra (Damo, 2007) é mais difícil de ser resguardada diante da sanha do fluxo do mercado. Dilemas históricos que reposicionam os torcedores e suas formas de torcer.

\section{Itaquera, um bairro (quase) distante}

A cidade de São Paulo é administrativamente repartida em 31 subprefeituras, as quais comportam 96 distritos administrativos onde, por sua vez, se localizam centenas de bairros. O distrito de Itaquera está localizado numa macrorregião, a zona leste, que abriga $37 \%$ da população da metrópole. A subprefeitura de Itaquera, de mesmo nome que o distrito, abriga ainda outros três distritos (Cidade Líder, José Bonifácio e Parque do Carmo). Dados do último senso da prefeitura, de 2010, totalizam no distrito de Itaquera 204.871 habitantes distribuídos em $14,6 \mathrm{~km}^{2}$, o que confere uma densidade demográfica de 14.032 habitantes por $\mathrm{km}^{2}$.

Segundo o Observatório Cidadão Nossa São Paulo, ${ }^{26}$ Itaquera estava em 2012 entre os bairros com pior índice de desemprego, totalizando 11,6\% de pessoas acima dos 16 anos nessa condição, sendo que os menores índices localizam-se nos bairros da zona oeste e sudoeste, Pinheiros, Lapa, Butantã

${ }_{26}$ Ver os dados da subprefeitura de Itaquera (http://www.nossasaopaulo.org.br/observatorio/regioes. php?regiao=29). 
(6,8\%). Neste último, para fins comparativos, está localizado o bairro do Morumbi e o estádio do São Paulo Futebol Clube. ${ }^{27}$ Para alguma visualização comparativa entre esses bairros em termos de violência envolvendo adolescentes em atos ditos infracionais, que seleciono porque é aí nessa faixa etária que também se recrutam torcedores mais engajados, os números revelam que em Itaquera tais índices alcançam 5,47\%, ao passo que o distrito do Butantã contabiliza 2,44\% e Pinheiros, $0,64 \%$. Índices como o IDH apontam ainda que no conjunto dos distritos Itaquera ocupa a $76^{\mathrm{a}}$ posição $(0,795)$ e o Morumbi, a $13^{\mathrm{a}}$ posição $(0,938)$ (São Paulo, 2007).

Para além desses índices mensuráveis e produzidos pelas estatísticas algumas categorias marcadamente simbólicas, por exemplo a noção de lugar, entre outras, permitem uma comparação mais etnográfica entre bairros. A emoção incontida expressa nos olhares torcedores diante da obra de engenharia vai imprimindo não somente o sentimento de pertença típico dos mecanismos simbólicos de adesão clubística, como vai relativizando a lonjura de Itaquera para aqueles que mal a concebiam como traçado urbano disponível, claramente expressa na fala elitista do presidente do São Paulo Futebol Clube mencionada mais acima.

E outras indagações que ouço no convívio com torcedores tais como "puxa, Itaquera não é tão feia assim" somam-se a outras tantas percepções que, desde 2010, momento em que a proposta do estádio em Itaquera se desenhou, têm mobilizado a percepção popular local a respeito de mais um estádio na cidade, bem como sua viabilidade do ponto de vista dos empreendimentos locais. Embates que alcançam a população em comentários comumente externados em vários espaços, tais como observados na internet:

Bem, estádio gera progresso a uma região? A maior das mentiras afirmar isso! É só ter em mente que torcedores só vão aos estádios assistir aos jogos e não fazer um passeio como em shoppings! E a maioria dos "torcedores" de hoje só

\footnotetext{
27 Ao contrário de Itaquera, caracterizada com um bairro-dormitório, o Morumbi viu na construção do estádio do São Paulo e na transferência do governo estadual para o Palácio do Morumbi um processo de gentrificação: “A região foi tomando 'ares' de nobreza, lugar de mansões das elites, que foram se deslocando dos Campos Elíseos, no início do século XX, para Higienópolis e Av. Paulista, a partir dos anos 30, e para os Jardins, nos anos 40-50. Nos anos 60, o ciclo de novos loteamentos que se abriu encontrou, na região do Morumbi, áreas propícias. Era o sonho da casa própria via a construção de uma minimansão, para muitos profissionais liberais, professores universitários, comerciantes etc. - as novas camadas médias então ascendentes." (Gohn, 2010, p. 273).
}

Horizontes Antropológicos, Porto Alegre, ano 19, n. 40, p. 149-184, jul./dez. 2013 
vão mesmo para fazer anarquias e... praticar pequenos e ou até mesmo, grandes roubos, pois estes ditos "torcedores" e uma grande parcela estão vinculados a entidades ilegais que são comandadas por traficantes, então, que progresso isso trás á uma região ${ }^{28}$

Ou:

Realmente, Itaquera (sou moradora) é tão pobre... dizem que está melhorando... Eu não acredito que construções de 4 ou 5 prédios já seja uma mudança. Pra Itaquera melhorar terá que explodir tudo! E uma competição de quem faz a "casa" mais feia! Fora que as pessoas, a grande maioria não tem cultura alguma...Vc vê por todos os lados meninas de 15 anos com 1 ou 2 filhos... grupinho de noia... Essa é a minha opinião! Eu moro na Cohab II e só Deus sabe como eu odeio esse lugar! Não pelo lugar em si, mas pela gentalha... [...] Coitada da minha mãe que acredita que com a construção do estádio do "curintia" a região vai se valorizar e a nossa casa tbm. Ela está doida pra vender e sumir de lá rsrs. ${ }^{29}$

Seguido das respostas:

Sua Mãe não está doida. Com a construção do estádio a sua casa irá se valorizar sim. Aproveite. ${ }^{30}$

Uma coisa não tem nada a ver com a outra. Não confunda. O estádio traz emprego, investimento e se abrir a copa trará BILHÕES para São Paulo. ${ }^{31}$

De qualquer modo a percepção local torcedora faz aproximar os espaços ou os integram num plano mais amplo de apreciações políticas perscrutando os caminhos mais sinuosos da metrópole e verdadeiramente a alargam para além de seus imperativos administrativos, fronteiras físicas ou sociológicas

${ }^{28}$ Comentário postado em 5 de junho de 2011 por J. L. Pereira Zucceronni ao texto de Douglas Nascimento (2010) no site São Paulo Antiga.

29 Postado em 25 de julho de 2011 por "aquinaojacaré" no mesmo conjunto de comentários citados em nota anterior.

${ }^{30}$ Postado em 6 de setembro de 2011 por "Ricardo" no mesmo conjunto de comentários.

31 Outro comentário postado por "Ricardo" no mesmo dia 6 de setembro de 2011. 
que, mobilizadas pelas transformações urbanísticas em curso, podem ser relidas pela lógica da emoção. ${ }^{32}$

Do ponto de vista torcedor a mera curiosidade, surpresa, percepção desconfiada de todo esse processo acaba produzindo o exercício contínuo de avaliação e de especulação, de cobrança, de presença, forj(ç)ando alguma discussão pública, ainda que perdida na recusa ou hesitação diante das alianças políticas, esportivas e urbanísticas sabidamente costuradas alhures, desejo alentado pelos interesses políticos e econômicos vindos de muitos lugares, mas também demanda da emoção torcedora que não ignora, ou que não parece alheia ao fato esportivo e urbano de tamanha magnitude.

\section{Estádio, coisa viva}

Chamado não consensualmente de "Itaquerão", outras vezes de "Fielzão", detratado pelas torcidas adversárias como "Gambazão", o estádio completará suas arquibancadas monumentais em torno do campo quando da sua edificação definitiva, criando o espaço ritualístico das reificações esportivas, potencializando a lucratividade na Copa do Mundo e depois dela, e redefinirá em parte o corintianismo pré-estádio, aquele alimentado pela falta, pelo quase, enfim, categorias que por muito tempo delinearam alguns dos contornos de uma forma expressiva de torcer.

Proposto aqui como extensão física ou forma que se empresta ao corintianismo o estádio não conecta apenas o local ao global, uma forma de torcer ao megaevento que se avizinha. Coextensivos, ambos produzem entre si um contraponto e fazem do estádio um processo ininterrupto se o tomarmos também como evento a produzir, ligar e religar outros eventos. $\mathrm{O}$ estádio como coisa viva seria "um 'acontecer', ou melhor, um lugar onde vários aconteceres se entrelaçam" porque para todos aqueles que se dirigem às obras, e aí pouco importa se observadores (antropólogo) ou observados (torcedores,

${ }^{32}$ Contrastando às inquietações dos moradores e torcedores, pode ser interessante assistir ao vídeo institucional do Comitê Paulista de organização da copa a respeito do "masterplan" dos seis jogos destinados a São Paulo. Misto de informação e propaganda política das administrações municipal e estadual, situa o estádio corintiano no conjunto das chamadas melhorias das condições infraestruturais da região de Itaquera com o advento da Copa de 2014 (Mais de 82\% .., 2012).

Horizontes Antropológicos, Porto Alegre, ano 19, n. 40, p. 149-184, jul./dez. 2013 
trabalhadores, dirigentes, empresários, políticos), “observar uma coisa não é ser trancado do lado de fora, mas ser convidado para a reunião" (Ingold, 2012, p. 29).

Reitero que megaevento não deve ser tomado somente como ponto discreto e atemporal ou receptáculo de interesses (condenáveis ou não) ou ainda síntese sublimada no jogo lúdico entre nações. Megaevento não deve ser pensado como uma excepcionalidade dentro das ordens simbólicas e valorativas das sociedades que patrocinam eventos dessa monta, pois são delas emanações espetaculares de suas configurações sociopolíticas que se fazem e desfazem o tempo todo. Se pensado somente do ponto de vista da racionalidade econômica, ainda que absolvido pelos usos culturalistas que o conceito de ritual impõe à copa, nada mais faríamos que reificar um autoengano em escala planetária, como parece advertir Damo (2012) diante das vertentes pessimistas em relação à realização da mesma. Não desqualifico ou minimizo tais críticas, apenas as coloco num jogo mais extenso de contrapontos, pois senão acabamos, por fim, a condenar como alienados todos aqueles que estão mais à margem da crítica economicista ou moral que, no final das contas, pressupõe que exista em algum lugar uma boa sociedade esportiva.

Um dos aspectos do caráter universalizado do megaevento esportivo reside no seu poder agentivo econômico em torno dos interesses políticos nem sempre republicanos e democráticos (Comitê Popular Rio da Copa e das Olimpíadas, 2012; Proni; Silva, 2012), por certo, mas sua ocorrência mobiliza e entrecorta fluxos locais menos evidentes e universalistas, tais como o observado aqui no corintianismo apreendido pela escrita etnográfica. E que impacta, espécie de legado imaterial, a socialidade torcedora não exatamente pelos mesmos motivos instrumentais ou escusos que o levaram a se impor politicamente no país.

Local e global não são exatamente duas ordens de grandeza em torno das mesmas coisas, dos mesmos projetos e valores, das mesmas políticas, e nada parece indicar que exista uma simetria entre local e global que projete em um exatamente aquilo que foi produzido sob escala superdimensionada no outro. Não se trata aqui de uma relação de determinação pura e simples.

As estratégias simbólicas dos torcedores anônimos que se convidam para a reunião, ou seja, apropriam, ainda que de fora, mas por dentro do corpo e da alma do estádio do Itaquerão, garantindo que ele cresça corintiano, tal como costumeiramente um pai atento impõe ao filho a escolha do time de futebol 
no domínio do parentesco esportivo, não deixa de ser uma estratégia política no interior do emaranhado de outras tantas estratégias em jogo, simbólicas ou instrumentais. Não há por que desconsiderá-la. E à medida que o estádio alienado à construtora, financiado pelo poder público, usado e logo descartado pela FIFA, acossado politicamente por outros agentes, toma sua forma definitiva na paisagem da zona leste, outros eventos ou megaeventos o colocarão novamente no fluxo de tantas apropriações simbólicas no jogo da sociopolítica esportiva. Explicitar o maior número possível de apropriações e estratégias é a intenção das etnografias futuras. Por hora procurei alinhavar alguns dos contornos de um processo de inclusão simbólica no interior de uma forma de torcer historicamente identificada por corintianismo, que segue ao ritmo das obras do estádio.

\section{Referências}

ALLIANZ PARQUE deve ser o novo nome do estádio do Palmeiras. Estadão.com.br, 29 maio 2013. Disponível em: <http://www.estadao.com. $\mathrm{br} /$ noticias/esportes, allianz-parque-deve-ser-nome-do-novo-estadio-dopalmeiras, 1036988,0.htm>. Acesso em: 2 jun. 2013.

APPADURAI, A. Putting hierarchy in its place. Cultural Anthropology, v. 3, p. 36-49, 1988.

ARENA CORINTHIANS - torcedores comemoram primeiro aniversário das obras da Arena. Meu Timão, 30 maio 2012. Disponível em: $<$ http://www. meutimao.com.br/noticia/77779/arena_corinthians -torcedores_comemoram primeiro_aniversario_das_obras_da_arena>.Acesso em: 30 maio 2012.

AUGÉ, M. Não-lugares: introdução a uma antropologia da supermodernidade. Campinas: Papirus, 1994.

BARCELOS NETO, A. Apapaatai: rituais de máscaras no Alto Xingu. São Paulo: Edusp; Fapesp, 2008.

BUARQUE DE HOLANDA, B. O clube como vontade e representação. Rio de Janeiro: Sete Letras; Faperj, 2010. 
BROMBERGER, C. Football, la bagatelle la plus sérieuse du monde. Paris: Bayard, 1998.

CLELAND, J. From passive to active: the changing relationships supporters and football clubs. Soccer \& Society, v. 11, n. 5, p. 537-552, 2010.

CLIFFORT, J. A experiência etnográfica: antropologia e literatura no século XX. Rio de Janeiro: Editora UFRJ, 2011.

COMITÊ POPULAR RIO DA COPA E DAS OLIMPÍADAS. Megaeventos e violações de direitos humanos no Rio de Janeiro: dossiê do Comitê Popular da Copa e Olimpíadas do Rio de Janeiro. 2012. Disponível em: <http:// www.apublica.org/wp-content/uploads/2012/09/dossic3aa-megaeventos-eviolac3a7c3b5es-dos-direitos-humanos-no-rio-de-janeiro.pdf $>$. Acesso em: 15 nov. 2012.

CURI, M. Espaços da emoção: arquitetura futebolística, torcida e segurança pública. Tese (Doutorado em Antropologia)-Instituto de Ciências Humanas e Filosofia, Universidade Federal Fluminense, Niterói, 2012.

DACOSTA, L. da; MIRAGAYA, A. Estado da arte do conhecimento sobre legados de megaeventos esportivos no exterior e no Brasil. In: DACOSTA, L. et al. (Org.). Legados de megaeventos esportivos. Brasília: Ministério do Esporte, 2008. p. 33-45.

DAMATTA, R. et al. (Org.). Universo do futebol. Rio de Janeiro: Pinakhotheke, 1982.

DAMO, A. Do dom à profissão: a formação de futebolistas no Brasil e na França. São Paulo: Hucitec, 2007.

DAMO, A. O concreto e o simbólico: os estádios de futebol como cultura material. Paper apresentado a $34^{\mathrm{a}}$ Anpocs. Caxambu, 2011. Mimeografado.

DAMO, A. O desejo, o direito e o dever - a trama que trouxe a Copa ao Brasil. Movimento, Porto Alegre, v. 18, n. 2, p. 41-81, 2012. 
GEIGER, A. Apresentação. In: BATESON, G. Naven. São Paulo: Edusp, 2008. p. 23-67.

GIDDENS, A. As conseqüências da modernidade. São Paulo: Editora da Unesp, 1991.

GOHN, M. da G. Morumbi, o contraditório bairro-região de São Paulo. Caderno CRH, Salvador, v. 59, n. 23, p. 267-281, 2010.

GOLDMAN, M. Alguma antropologia. Rio de Janeiro: Relume Dumará, 1999.

GUEDES, S. G. Futebol e identidade nacional: reflexões sobre o Brasil. In: DEL PIORI, M.; MELO, V. A. de. (Org.). História do esporte no Brasil. São Paulo: Editora da Unesp, 2009. p. 453-480.

HANNERZ, U. Fluxos, fronteiras, híbridos: palavras-chave da antropologia transnacional. Mana, Rio de Janeiro, v. 3, n. 1, p. 7-39, 1997.

HISTÓRIA DO SITE. Arena Timão Ao Vivo, 2011. Disponível em: $<$ http:// www.arenatimaoaovivo.com.br/historia.html>. Acesso em: 24 maio 2012.

HUIZINGA, J. Homo ludens. São Paulo: Perspectiva, 1993.

INGOLD, T. Trazendo as coisas de volta à vida: emaranhados criativos num mundo de materiais. Horizontes Antropológicos, Porto Alegre, ano 18, n. 37, p. 25-44, jan./jun. 2012.

KFOURI, J. Palma de lata. UOL Esporte, 8 nov. 2012. Disponível em: $<$ http:// blogdojuca.uol.com.br/2012/11/palma-de-lata/>. Acesso em: 9 nov. 2012.

LAGROU, E. A fluidez da forma: arte, alteridade e agência em uma sociedade amazônica [Kaxinawá, Acre]. Rio de Janeiro: Topbooks, 2007.

LEITE, A.; FAVERO, P. Corintiano ganha estádio que terá a sua própria cara. Estadão.com.br, 1 dez. 2012. Disponível em: <http://www.estadao. com.br/noticias/esportes, corintiano-ganha-estadio-que-tera-a-sua-propriacara,967911,0.htm>. Acesso em: 2 dez. 2012. 
LÉVI-STRAUSS, C. História e etnologia. Campinas: IFCH/Unicamp, 2004.

MAIS DE $82 \%$ do público em Itaquera usará transporte coletivo na Copa. Sport Club Corinthians Paulista, 5 jun. 2012. Disponível em: <http://www. corinthians.com.br/site/noticias/ver/?c=Arena + Corinthians\&id=15289>. Acesso em: 12 nov. 2012.

MARCONDES BRITO. Arena Pirituba, um novo estádio em SP. Marcondes Brito, 14 abr. 2010. Disponível em: <http://blogs.band.com. br/marcondesbrito/2010/04/14/arena-pirituba-um-novo-estadio-em-sp/>. Acesso em: 13 nov. 2012.

MARCUS, G. Ethnography in/of the world system: the emergence of multisited ethnography. The Annual Review of Anthropology, n. 24, p. 95-117, 1995.

MASCARENHAS, G. Globalização e espetáculo: o Brasil dos megaeventos esportivos. In: DEL PIORI, M.; MELO, V. A. de. (Org.). História do esporte no Brasil. São Paulo: Editora da Unesp, 2009. p. 505-513.

NASCIMENTO, D. Estádio do Corinthians: um sonho antigo. São Paulo Antiga, 10 set. 2010. Disponível em: <http://www.saopauloantiga.com.br/ estadio-do-corinthians/>. Acesso em: 11 nov. 2012.

OFICIAL: Morumbi está fora da copa do mundo 2014. Estadão.com.br, 16 jun. 2010. Disponível em: <http://www.estadao.com.br/noticias/esportes,oficialmorumbi-esta-fora-da-copa-do-mundo-de-2014,567510,0.htm>. Acesso em: 13 nov. 2012.

OLIVEIRA, A. de; BEIRÃO, N. Aqui tem um bando de guerreiro. Brasileiros, n. 56, 26 mar. 2012. Disponível em: <http://www.revistabrasileiros.com. br/2012/03/26/aqui-tem-um-bando-de-guerreiro/>. Acesso em: 6 dez. 2012.

PELO $4^{\circ}$ ANO, Corinthians é o clube brasileiro com a marca mais valiosa. Placar, 13 maio 2013. Disponível em: <http://placarabril.com.br/materia/ pelo-4o-ano-corinthians-e-clube-brasileiro-com-a-marca-mais-valiosa $>$. Acesso em: 13 maio 2013. 
POYTER, G. Regeneração urbana e legado Olímpico de Londres 2012. In: DACOSTA, L. et al. (Org.). Legados de megaeventos esportivos. Brasília: Ministério do Esporte, 2008. p. 121-152.

PRONI, M. W.; SILVA, L. O. da. Impactos econômicos da Copa do Mundo de 2014: projeções superestimadas. Texto para Discussão, Campinas, n. 211, out. 2012. Disponível em: <http://www.ludopedio.com.br/rc/upload/files/122700_ TD211_Proni.pdf>. Acesso em: 2 dez. 2012.

SIMMEL. G. As grandes cidades e a vida do espírito. Mana, Rio de Janeiro, v. 11, n. 2, p. 577-591, 2005.

SANTOS, L. Triste sina ser poeta de latrina: um estudo antropológico sobre grafitos de banheiro. Dissertação (Mestrado em Antropologia Social)-Centro de Educação e Ciências Humanas, Universidade Federal de São Carlos, São Carlos, 2012.

SÃO PAULO. Secretaria Municipal do Desenvolvimento, Trabalho e Empreendedorismo. Atlas do trabalho e desenvolvimento da cidade de São Paulo. São Paulo, 2007.

TOLEDO, L. H. Lógicas no futebol. São Paulo: Hucitec; Fapesp, 2002.

TOLEDO, L. H. Políticas da corporalidade: socialidade torcedora entre 19902010. In: Toledo, L. H. et al. (Org.). A torcida brasileira. Rio de Janeiro: Sete Letras, 2012. p. 122-158.

TOLEDO, L. H. Ritual sem dono, evento sem nome. Os segredos da transformação da Copa do Mundo em um megaevento. Coletiva, Recife, n. 8, abr./maio/jun. 2012b. Disponível em: <http://www.coletiva.org/site/index. php?option $=$ com_k2\&view $=$ item\&layout $=$ item \&id $=100 \&$ Itemid $=76 \& \mathrm{idr}$ ev=11>. Acesso em: 6 dez. 2012.

VELHO, G. Unidade e fragmentação em sociedades complexas. In: VELHO, G. Projeto e metamorfose: antropologia das sociedades complexas. Rio de Janeiro: Zahar, 1994. p. 11-30. 
VEREADORES que se dizem corinthianos cobrarão contrapartidas de São Paulo e Palmeiras Blog do Paulinho, 4 maio 2012. Disponível em: <http:// blogdopaulinho.wordpress.com/2012/05/04/vereadores-que-se-dizemcorinthianos-cobrarao-contrapartidas-de-sao-paulo-e-palmeiras/>. Acesso em: 15 nov. 2012. 